\begin{tabular}{|ll}
\hline Received & $: 15$ Maret 2020 \\
Revised & $: 2$ April 2020 \\
Accepted & $: 20$ April 2020 \\
Online & $: 25$ April 2020 \\
Published & $: 30$ April 2020
\end{tabular}

\title{
Penggunaan Ab Mix dan Media Tanam terhadap Viabilitas Tanaman Selada (Lactuca sativa L. var. New Grand Rapids) dalam Hydroponic Wick System
}

\author{
Imam Safir Alwan Nurza ${ }^{1, a)}$, Diliviva Venesia ${ }^{2, b)}$ \\ ${ }^{1}$ Biologi, Fakultas Matematika dan Ilmu Pengetahuan Alam, Universitas Negeri Jakarta \\ ${ }^{2}$ Pendidikan Kimia, Fakultas Matematika dan Ilmu Pengetahuann Alam, Universitas Negeri Jakarta \\ $\checkmark:{ }^{\text {a) }}$ imamsafiralwannurza2017@gmail.com, ${ }^{\text {b) }}$ dilivivavenesia@gmail.com
}

\begin{abstract}
Indonesia is a country that has abundant natural resources. One of the natural resource wealth is in the agricultural sector. The agricultural sector has a variety of agricultural commodities found in Indonesia. One of them is horticulture. The purpose of this research was to find out the use of ab mix and planting media on lettuce (Lactuca sativa L. var. New Grand Rapids) in increasing growth and yield after 40 days after planting (HST). The research method used was an experiment with ab mix as a treatment and aquades as a control. The research results obtained are number of leaves, plant height, and wet weight in the ab mix is higher than aquades because the ab mix provides nutrients for plant growth so that the plant becomes tall and enlarged with its leaves looking wide. However, the number of seeds germinated and plant viability in ab mix was lower than aquades, which was $24.3 \%$ while aquades $32 \%$. This is because there is an inorganic salt in the ab mix which inhibits seed germination so that the seed membrane in absorbing water becomes impermeable. The research conclusion is the use of ab mix will be very effective if used after the seeds germinate.
\end{abstract}

Keywords: AB Mix, Aquades, Lettuce, Plants, Viability

\begin{abstract}
Abstrak
Indonesia merupakan negara yang memiliki sumberdaya alam melimpah. Kekayaan sumberdaya alam tersebut salah satunya pada sektor pertanian. Sektor pertanian memiliki berbagai macam komoditas pertanian yang terdapat di Indonesia. Salah satunya adalah hortikultura. Tujuan penelitian ini untuk mengetahui penggunaan ab mix dan media tanam terhadap tanaman selada (Lactuca sativa $\mathrm{L}$. var. New Grand Rapids) dalam meningkatkan pertumbuhan dan hasil panen setelah 40 Hari Setelah Tanam (HST). Metode penelitian yang digunakan adalah eksperimen dengan ab mix sebagai perlakuan dan aquades sebagai kontrol. Hasil penelitian ini adalah jumlah daun, tinggi tanaman, dan berat basah pada ab mix lebih tinggi daripada aquades (kontrol) karena ab mix menyediakan nutrisi untuk pertumbuhan tanaman sehingga tanaman menjadi tinggi dan membesar dengan daunnya yang tampak lebar. Namun, jumlah benih berkecambah dan viabilitas tanaman pada ab mix lebih rendah daripada aquades (kontrol), yaitu 24,3\% sedangkan aquades (kontrol) $32 \%$. Hal ini karena terdapat garam anorganik pada ab mix yang menghambat perkecambahan benih sehingga membran benih dalam menyerap air menjadi impermeabel. Kesimpulan penelitian ini adalah penggunaan ab mix akan menjadi sangat efektif jika digunakan setelah benih berkecambah.
\end{abstract}

Kata-kata kunci: AB Mix, Aquades, Selada, Tanaman, Viabilititas. 


\section{PENDAHULUAN}

Indonesia merupakan negara agraris yang memiliki sumber daya alam melimpah. Kekayaan sumber daya alam tersebut salah satunya adalah sektor pertanian. Sektor pertanian memiliki berbagai macam komoditas yang terdapat di Indonesia, baik berupa komoditas tanaman pangan, perkebunan, holtikultura, tanaman hias, maupun tanaman industri (Wibowo dan Asriyanti, 2017). Menurut Ananda (2015), Hortikultura adalah budidaya tanaman buah-buahan, sayuran, dan hias. Salah satu tanaman hortikultura adalah Selada (Lactuca sativa L.) yang merupakan komoditas hortikultura dengan prospek dan nilai komersial yang baik.

Menurut Wicaksono (2008), tanaman sayuran ini dikenal di masyarakat karena mengandung gizi cukup tinggi khususnya mineral. Dalam setiap $100 \mathrm{~g}$ selada, terkandung $15 \mathrm{kal}, 1.2 \mathrm{~g}$ protein, $0.2 \mathrm{~g}$ lemak, $2.9 \mathrm{~g}$ karbohidrat, $22.0 \mathrm{mg} \mathrm{Ca}, 25 \mathrm{mg} \mathrm{P}, 0.5 \mathrm{mg} \mathrm{Fe}, 540$ SI vitamin A, 0.04 SI vitamin B, dan $94.8 \mathrm{~g}$ air. Selada sebagai bahan makanan dapat dikonsumsi dalam bentuk segar sebagai lalapan yang dimakan bersama dengan bahan makanan lain. Selada (Lactuca sativa L.) juga merupakan sayuran daun yang berasal dari daerah (negara) beriklim sedang.

Penelitian ini menggunakan hidroponik sistem Wick. Menurut Trisna et al. (2017), sistem ini menggunakan bahan-bahan daur ulang seperti botol atau gelas plastik bekas minuman kemasan sebagai wadah untuk nutrisi dan kain flanel sebagai sumbu untuk menyerap nutrisi. Lalu, media tanam yang digunakan dalam hidroponik ini adalah rockwool. Rockwool adalah bahan yang dibuat dengan peniupan uap pada batuan yang telah dilelehkan. Menurut Rizka et al. (2016), hasilnya adalah sejenis fiber yang memiliki rongga-rongga dengan diameter umumnya antara 6-10 mikromoter. Kemudian, untuk pertumbuhan tanaman Selada (Lactuca sativa L.) menggunakan nutrisi ab mix dalam bentuk larutan.

Menurut Sutiyoso (2004), nutrisi ab mix adalah nutrisi yang digunakan dengan dibagi menjadi dua stok, yaitu stok a dan stok b. Stok a berisi senyawa yang mengandung kalsium (Ca), sedangkan stok $\mathrm{b}$ berisi senyawa yang mengandung sulfat dan fosfat. Pembagian tersebut dimaksudkan agar dalam kondisi pekat tidak terjadi endapan karena kalsium (Ca) jika bertemu dengan sulfat atau fosfat dalam keadaan pekat menjadi kalsium sulfat atau kalsium fosfat dan membentuk endapan. Nutrisi ab mix mengandung unsur hara yang sangat diperlukan oleh tanaman, diantaranya makro dan mikro. Unsur Makro, yaitu N, P, K, Ca, Mg, S, dan mikro, yaitu Fe, Mn, Bo, Cu, Zn, Mo, Cl, Si, Na, Co (Agustina, 2004).

Oleh karena itu, penelitian ini bertujuan untuk mengetahui penggunaan ab mix dan media tanam terhadap tanaman selada (Lactuca sativa L. var New Grand Rapids) dalam meningkatkan pertumbuhan dan hasil panen setelah 40 Hari Setelah Tanam (HST). Maka dari itu, peneliti berharap dengan dilakukan penelitian ini dapat menjadi informasi dan pengetahuan bagi banyak masyarakat.

\section{METODE}

Penelitian ini dilakukan pada tanggal 19 November - 27 Desember 2019. Lokasi penelitian ini di Daksinapati Timur, Rawamangun, Jakarta timur. Metode yang digunakan berupa eskperimen (true experiment) dengan menggunakan perlakuan dan kontrol. Perlakuan pada tanaman menggunakan ab mix dan kontrol menggunakan aquades.

Pada penelitian ini dipersiapkan alat dan bahan berupa baki, cutter, gunting, penggaris, botol, benih Selada (Lactuca sativa L. var. New Grand Rapids), rockwool, aquades $4500 \mathrm{ml}$, larutan kloroks $50 \mathrm{ml}$, bubuk ab mix, erlenmeyer $1000 \mathrm{ml}$, gelas ukur $25 \mathrm{ml}$, gelas ukur $10 \mathrm{ml}$, kain flanel berukuran $15 \times 1 \mathrm{~cm}$, dan gelas plastik sebanyak 200. Disterilisasi 200 benih dengan menggunakan 10\% larutan kloroks dengan perbandingan 1:9 dan ditunggu selama 10 menit. Setelah itu, 10 menit air yang mengandung larutan kloroks dibuang dan diganti dengan aquades untuk dibilas, lalu dikeringkan. Kemudian dipersiapkan penanaman dengan rockwool yang dipotong sebesar 2,5 x 2,5 $\mathrm{cm}$ dan diletakkan di gelas plastik. Diisi gelas plastik dengan rockwool dan kain flanel $15 \mathrm{x} 1 \mathrm{~cm}$. Diletakkan per benih pada setiap rockwool yang telah dipotong. Lalu, pembuatan larutan nutrisi ab mix dengan ditambahkan aquades $900 \mathrm{ml}$ dengan larutan a $5 \mathrm{ml}$ dan diaduk kemudian ditambahkan larutan b $5 \mathrm{ml}$ dan diaduk kembali, kemudian ditambahkan aquades sampai $1000 \mathrm{ml}$. Setelah itu, gelas plastik yang berisi rockwool dengan benih diisi larutan ab mix dan kontrol dengan aquades.

e-Journal : http://ejurnal.kpmunj.org 
Variabel penelitian ini adalah jumlah benih berkecambah, jumlah daun, tinggi tanaman, berat basah, dan viabilitas pada tanaman selada (Lactuca sativa L. var. New Grand Rapids). Kemudian, teknik pengumpulan data yang digunakan adalah deskriptif kuantitaif dengan mengukur jumlah benih berkecambah, jumlah daun, tinggi tanaman, viabilitas, dan menimbang berat basah. Berat basah ditimbang pada hari ke-40 hari setelah tanam (HST). Kemudian, data diolah secara statistika. Teknik analisis data yang dilakukan dengan menggunakan microsoft excel 2010 dari data yang telah didapatkan selama 40 hari.

\section{HASIL DAN PEMBAHASAN}

\section{Jumlah Benih Berkecambah}

Jumlah yang berkecambah pada benih tanaman selada (Lactuca sativa L. var. New Grand Rapids) menunjukkan bahwa aquades (kontrol) dapat meningkatkan jumlah kecambah benih tanaman dibandingkan dengan ab mix yang dapat dilihat pada Gambar 1 . Hal ini karena aquades yang masuk ke dalam benih menyebabkan benih mengembang dan terjadi reaksi metabolisme yang mengaktifkan enzim $\alpha$-amilase untuk mengubah glukosa menjadi energi sehingga benih dapat berkecambah.

Selain enzim, hormon zat pengatur tumbuh (ZPT) juga merangsang perkecambahan benih. Zat pengatur tumbuh (ZPT) tersebut adalah giberelin. Menurut Purwaningsih (2001), giberelin merupakan hormon zat pengatur tumbuh (ZPT) yang dapat merangsang aktivitas enzim dan berperan dalam proses perkecambahan benih.

Keduanya ini sangat penting terhadap perkecambahan benih. Benih tanaman selada (Lactuca sativa L. var. New Grand Rapids) yang menggunakan ab mix sedikit berkecambah karena terdapat garam anorganik yang dapat menghambat perkecambahannya. Garam anorganik ini adalah Kalium Nitrat $\left(\mathrm{KNO}_{3}\right)$. Sedangkan menggunakan aquades (kontrol) benih dapat berkecambah lebih banyak.

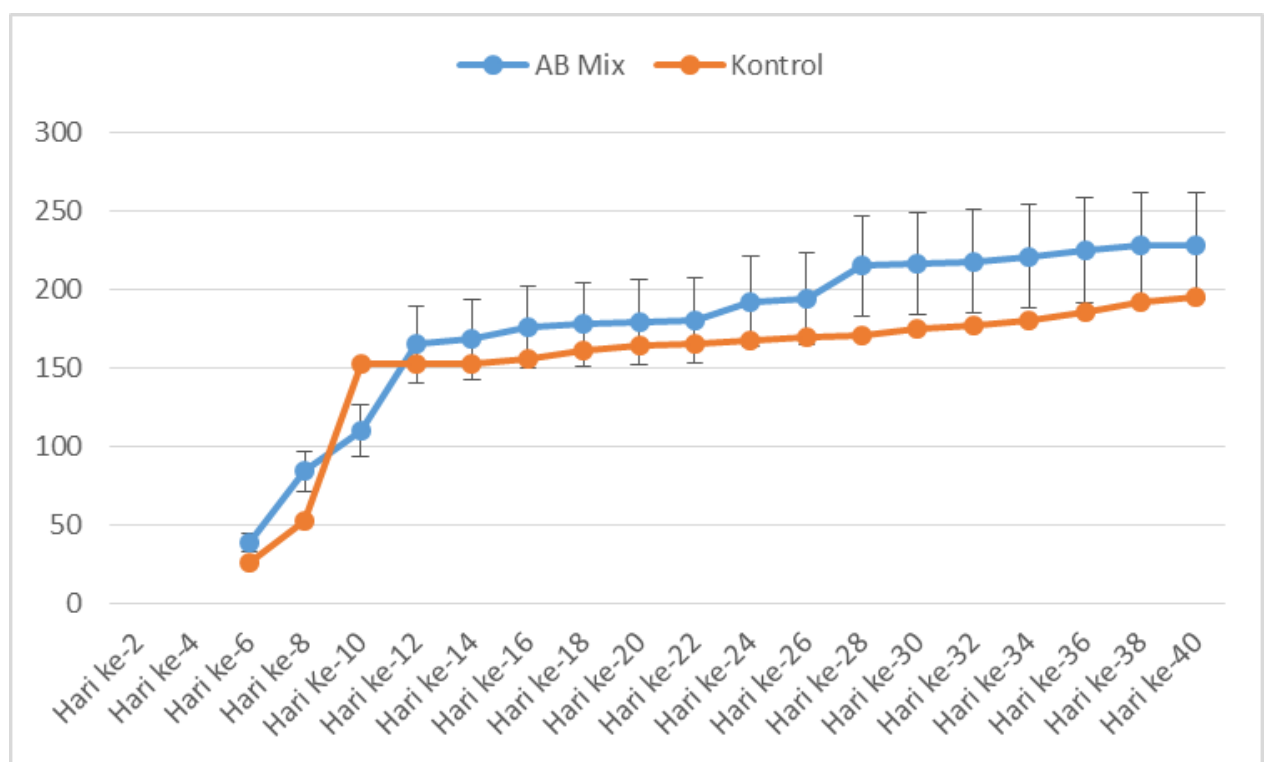

GAMBAR 1. Jumlah berkecambah tanaman selada per 2 hari selama 40 hari (SE 5\%)

\section{Jumlah Daun}

Jumlah daun tanaman selada (Lactuca sativa L. var. New Grand Rapids) dengan menggunakan ab mix menunjukkan dapat menghasilkan daun yang lebih banyak dibandingkan dengan aquades (kontrol) yang dapat dilihat pada Gambar 2. Hal ini karena kandungan yang terdapat pada ab mix dapat merangsang pertumbuhan daun dengan cepat dan banyak daripada hanya menggunakan aquades (kontrol).

Jumlah daun yang banyak dihasilkan ini diinduksi oleh hormon sitokinin. Hormon ini merupakan salah satu zat pengatur tumbuh (ZPT). Sitokinin merupakan senyawa turunan adenin yang digunakan 
untuk memicu inisiasi dan proliferasi tunas. Sitokinin dalam jaringan tanaman berperan dalam proses pembelahan sel, menunda penuaan daun, meningkatkan ukuran dan jumlah daun, dan morfogenesis (Gunawan, 1988; Parnata, 2010; Karjadi et al., 2008; Zulkarnain, 2009; Rabbani et al., 2010; Lina dan Wahyono, 2013; Kasli, 2009). Morfogenesis yang dimaksud pada tanaman selada (Lactuca sativa L. var. New Grand Rapids) adalah pembentukan daun, sehingga jika tanaman yang mendapatkan unsur makro (Kalium (K), Kalsium (Ca), Magnesium (Mg), dan Sulfur (S)) dan mikro (Besi (Fe), Mangan (Mn), Mo (Molibdenum (Mo), dan Tembaga (Cu)) akan diatur oleh sitokinin untuk membentuk dan menghasilkan daun yang baik.

Tanaman yang mendapatkan unsur makro (Kalium (K), Kalsium $(\mathrm{Ca})$, Magnesium $(\mathrm{Mg})$, dan Sulfur (S)) dan mikro (Besi (Fe), Mangan (Mn), Mo (Molibdenum (Mo), dan Tembaga (Cu)) dari ab mix dapat menumbuhkan daun dengan baik dengan warna hijau tanpa garis kuning di tepi daun, spot kuning di ujung daun, warna kuning pada keseluruhan daun, dan warna ungu serta mencegah kerontokan pada daun.

Daun yang banyak dihasilkan dapat menghasilkan fotosintat yang banyak dari hasil fotosintesis. Hal ini karena banyaknya cahaya yang ditangkap oleh klorofil sehingga terjadi proses fotosintesis yang menghasilkan fotosintat, kemudian fotosintat ini dialirkan ke seluruh tanaman sehingga tanaman yang memiliki daun lebih banyak sangat baik dalam mendapatkan cahaya dibandingkan dengan daun yang sedikit. Oleh karena itu, tanaman yang menggunakan ab mix sangat baik dalam menghasilkan daun dibandingkan hanya menggunakan aquades kontrol.

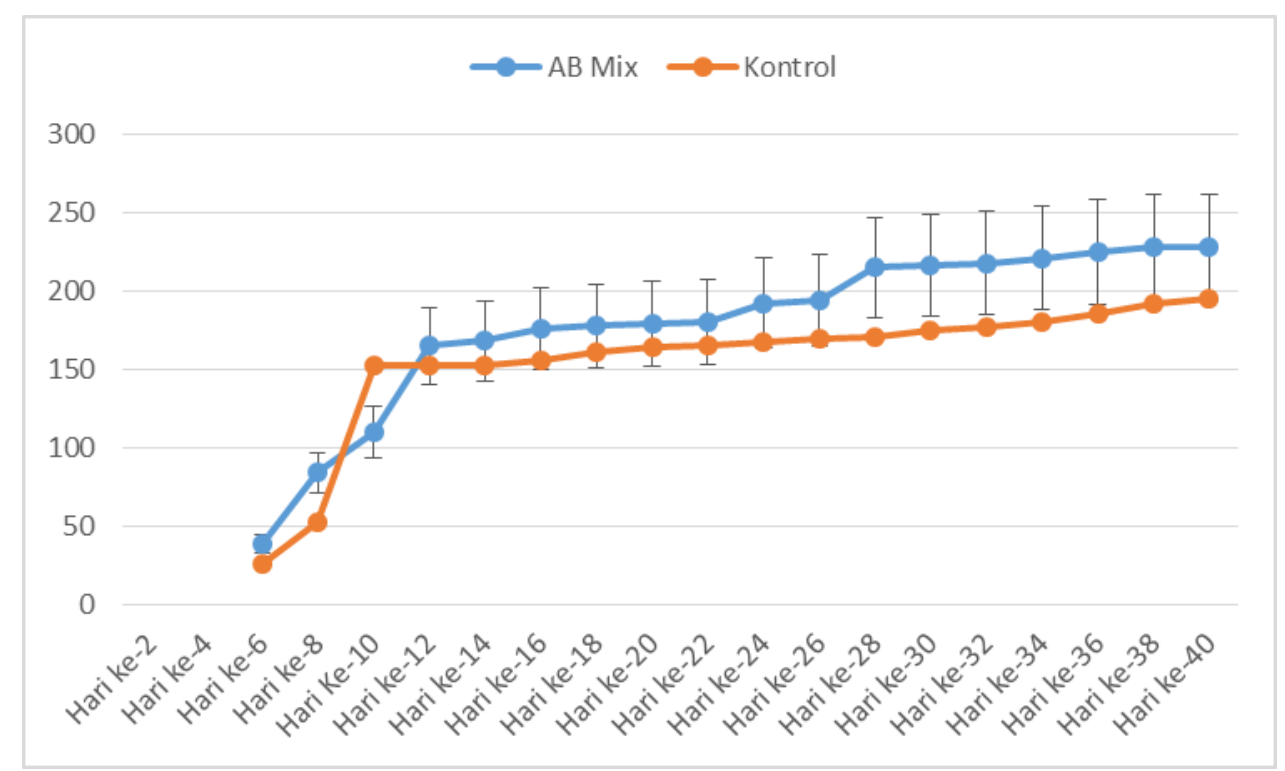

GAMBAR 2. Jumlah berkecambah tanaman selada per 2 hari selama 40 hari (SE 5\%)

Tinggi Tanaman

Tinggi tanaman selada (Lactuca sativa L. var. New Grand Rapids) dengan menggunakan ab mix menunjukkan bahwa dapat meningkatkan tinggi tanaman dibandingkan hanya menggunakan aquades (kontrol). Hal ini karena nutrisi dari ab mix yang diterima oleh tanaman mengandung unsur makro (Nitrogen (N), dan Fosfat (P)) dan mikro ( Boron (B) dan Seng (Zn)). selain itu, hormon zat pengatur tumbuh (ZPT) yang terdapat pada tanaman tersebut dapat mempercepat tinggi tanaman, zat pengatur tumbuh (ZPT) yang ada pada tanaman tersebut adalah auksin. Auksin adalah senyawa dengan ciriciri mempunyai kemampuan dalam mendukung terjadinya perpanjangan sel pada pucuk dengan struktur kimia indole ring, banyak auksin di dalam tanaman sangat mempengaruhi pertumbuhan tanaman (Abidin, 1987; Birkemeyer et al., 2003; Ljung et al., 2001).

Pemberian air yang bernutrisi pada tanaman dalam waktu yang intensif dapat memberikan peningkatan pertumbuhan tanaman sehingga tinggi tanaman dapat berubah secara signifikan. Perbedaan tinggi tanaman pada ab mix dan aquades (kontrol) terlihat sangat jelas yang dapat dilihat pada Gambar 3. 


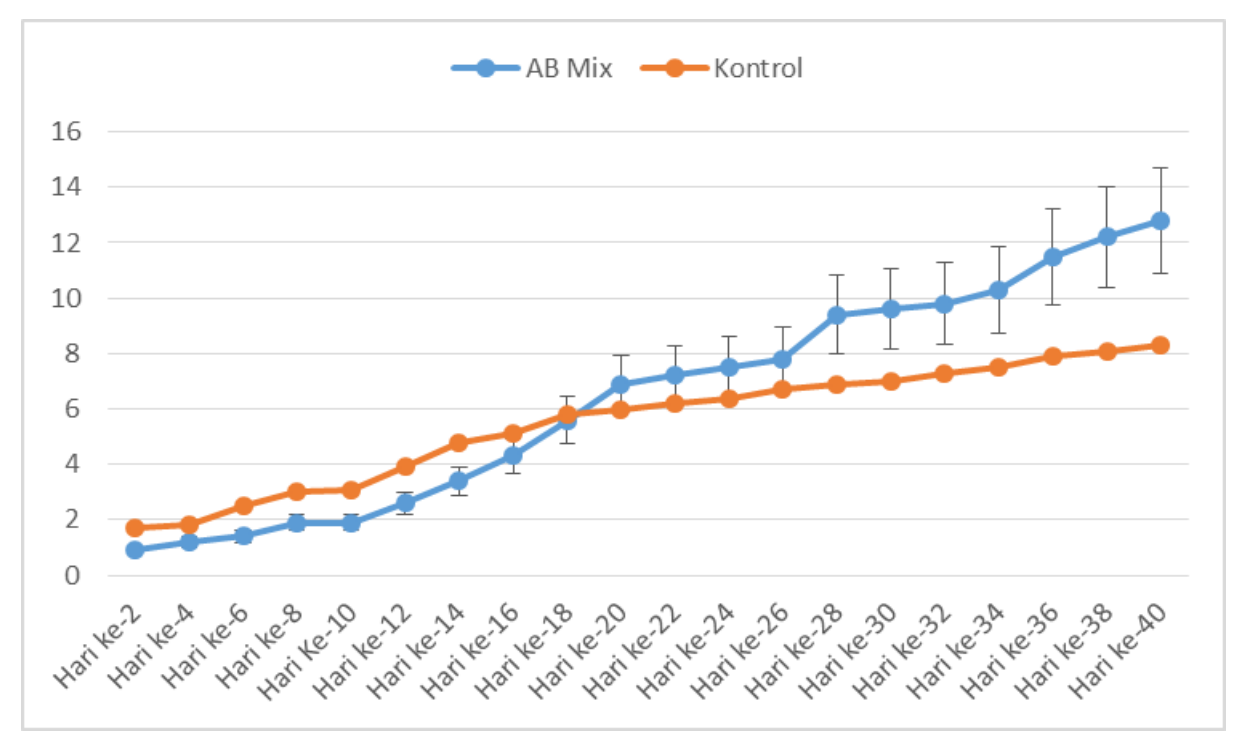

GAMBAR 3. Jumlah berkecambah tanaman selada per 2 hari selama 40 hari (SE 5\%)

\section{Berat Basah dan Viabilitas}

Berat basah tanaman selada (Lactuca sativa L. var. New Grand Rapids) dengan ab mix menunjukkan bahwa dapat meningkatkan berat tanaman dibandingkan hanya menggunakan aquades (kontrol). Hal ini karena kandungan air yang terdapat pada tanaman sehingga pertumbuhan meningkat dan tanaman membesar.

Menurut Lakitan (2012), berat basah tanaman sangat dipengaruhi oleh kadar air yang terdapat pada jaringan tanaman. Selain kandungan air, nutrisi yang diserap berupa unsur makro (Nitrogen $(\mathrm{N})$, Fosfat (P), Kalium (K), Kalsium (Ca), Magnesium (Mg), dan Sulfur (S)) dan unsur mikro (Besi (Fe), Boron (B), Mangan (Mn), Tembaga (Cu), Molibdenum (Mo), dan Seng ( $\mathrm{Zn})$ ) dapat meningkatkan hasil fotosintesis berupa fotosintat sehingga berat tanaman dapat bertambah. Sedangkan rata-rata viabilitas tanaman selada (Lactuca sativa L. var. New Grand Rapids) dengan ab mix menunjukkan 24,3\% dan air (kontrol) 32\%.

Viabilitas benih tanaman selada (Lactuca sativa L. var. New Grand Rapids) dengan menggunakan aquades (kontrol) sangat baik dalam meningkatkan vabialitas benih karena saat air masuk ke dalam benih tidak membawa garam anorganik. Garam anorganik dapat menurunkan viabilitas benih karena dapat membuat membran pada benih dalam menerima air menjadi impermeabel sehingga viabilitas tanaman dengan menggunakan ab mix lebih rendah daripada air (kontrol). Berat basah dan viabilitas tanaman selada (Lactuca sativa L. var. New Grand Rapids) dapat dilihat pada Tabel 1.

TABEL 1. Berat basah dan viabilitas tanaman selada

\begin{tabular}{rlll}
\hline No & Perlakuan & Berat basah $(\mathrm{g})$ & Viabilitas $(\%)($ Mean \pm SE) \\
\hline 1 & AB Mix & 45,6 & $24,3 \pm 8,0$ \\
2 & Kontrol & 2,7 & $32 \pm 4,4$ \\
\hline
\end{tabular}

\section{KESIMPULAN}

Viabilitas tanaman dan jumlah benih berkecambah dengan menggunakan rockwool sebagai media tanam dan nutrisi ab mix dapat mendukung benih berkecambah. Namun, viabilitasnya lebih rendah daripada aquades (kontrol), yaitu 24,3\% sedangkan aquades (kontrol) 32\%. Hal ini karena terdapat garam anorganik yang menghambat benih berkecambah. Tetapi, jumlah daun, tinggi tanaman, dan berat basah pada ab mix lebih tinggi daripada aquades (kontrol) sehingga akan menjadi sangat efektif jika penggunaan ab mix digunakan setelah benih berkecambah. 


\section{REFERENSI}

Abidin, Z. (1987). Dasar-Dasar Pengetahuan Ilmu Tanaman. Bandung: Angkasa.

Agustina. (2004). Dasar Nutrisi Tanaman. Jakarta: Rineka Cipta.

Andana, Erie Kresna. 2015. Pengembangan data citra satelit landsat-8 Untuk pemetaan area tanaman hortikultura Dengan berbagai metode algoritma indeks Vegetasi (studi kasus: kabupaten malang dan sekitarnya). Prosiding Seminar Nasional Manajemen Teknologi XXII: 1-10.

Birkemeyer, C., Kolasa, A., \& Kopka, J. (2003). Comprehensive chemical derivatization for gas chromatography-mass spectrometry-based multi targeted profiling of the major phytohormones. Journal of Chromatography A. 993 (1): 89-102.

Copeland, L.D. (1976). Principles of Seed Science and Technology. Minneapolis, Minesota: Buegess Pub. Co.

Gunawan, L. (1988). Teknik Kultur Jaringan Tumbuhan. Bogor: Institut Pertanian Bogor.

Karjadi, A.K., Buchory A. (2008). Pengaruh Auksin dan Sitokinin terhadap Pertumbuhan dan Perkembangan Jaringan Meristem Kentang Kultivar Granola. Jurnal Hortikultura. 18 (4): 380384.

Kasli. (2009). Upaya Perbanyakan Tanaman Krisan (Crysanthemum sp.) Secara In Vitro. Jerami. 2 (3): 121-125.

Lakitan. B. (2012). Dasar-Dasar Fisiologi Tumbuhan. Jakarta: Raja Press.

Lina, F. R. R., dan Wahyono, R. (2013). Pengaruh 6-benzylamino purine (BAP) dan 6-furfuryl amino purine (Kinetin) pada Media MS terhadap Pertumbuhan Eksplan Ujung Apikal Tanaman Jati secara In Vitro. LenteraBio. 2 (1): 167-178.

Ljung, K., Bhalerao, R.P., \& Sandberg, G. (2001). Sites and homeostatic control of auxin biosynthesis in Arabidopsis during vegetative growth. The Plant Journal. 28 (4): 465-474.

Parnata, A. D. (2010). Meningkatkan Hasil Panen dengan Pupuk Organik. Jakarta: PT AgroMedia Pustaka.

Purwaningsih, O. (2001). Kajian Fisiologis dan Biokimiawi Benih Rambutan Sealam Penyimpanan Dengan Perlakuan ABA dan GA3. Ilmu Pertanian. 8 (2): 66-75.

Rabbani, M.A., M.S. Masood, Z.K. Shinwari and K. Yamaguchi-Shinozaki. (2010). Genetic analysis of basmati and non-basmati Pakistani rice (Oryza sativa L.) cultivars using microsatellite markers. Pak. J. Bot. 42: 2551-2564.

Rizka et al. (2016). Pertumbuhan dan hasil pakchoi (Brasicca rapa L.) Pada dua sistem Hidroponik dan Empat Jenis Nutrisi. Jurnal Kelitbangan. 4 (1): 2-3.

Sutiyoso, S. (2004). Meramu Pupuk Hidroponik. Jakarta: Swadaya.

Trisna, et al. (2017). Hidroponik untuk Pemula. Manado: Universitas Sam Ratulangi.

Wicaksono, A. (2008). Penyimpanan Bahan Makanan Serta Kerusakan Selada. Yogyakarta: Fakultas Politeknik Kesehatan.

Wibowo, S., Asriyanti, S. A. (2017). Aplikasi Hidroponik NFT pada Budidaya Pakcoy (Brassica rapa chinensis). Jurnal Penelitian Pertanian Terapan.13 (3): 159-167.

Zulkarnain. (2009). Dasar-dasar Hortikultura. Jakarta: Bumi Aksara. 